кандидат педагогічних наук, доцент

(Кременчуцький національний університет імені Михайла Остроградського) myboxua13egmail.com

ORCID: 0000-0003-2117-626X

\title{
ВИКОРИСТАННЯ ІНФОРМАЦЙНОЇ ТЕХНОЛОГІЇ ЕЛЕКТРОННОГО ПОРТФОЛІО В ОСВІТНЬОМУ ПРОЦЕСІ ВНЗ
}

У статті розглянуто роль інформаційної технології електронного портфоліо в активізацї наукової діяльності студентів ВНЗ та в процесі моніторингу й оцінки ї̈ результатів з метою оптимізації складання рейтингу успішності. Створення в інформаційному середовищі ВНЗ бази електронних портфоліо наукових досягнень студентів сприяє побудові єдиної автоматизованої індексно-рейтингової системи оцінювання.

\section{Ключові слова: електронне портфоліо, інформаційні технології в освіті, наукова діяльність, рейтингування.}

Постановка проблеми. В умовах встановлення на державному рівні нових вимог до призначення студентам вищих навчальних закладів академічних стипендій актуальності набуває оптимізація рейтингування навчальних та наукових досягнень студентів. Постановою Кабінету міністрів України "Деякі питання стипендіального забезпечення" встановлено, що академічні стипендії призначаються згідно з рейтингом успішності, який складається на підставі навчальних досягнень студента протягом останнього навчального семестру по кожному факультету, курсу, спеціальності. При цьому складова успішності у рейтингу складає не менше 90 відсотків рейтингового балу. Процедура визначення рейтингових балів визначається навчальним закладом [1]. Решту (10 відсотків) рейтингових балів студент може отримати за досягнення у науковій діяльності та завдяки громадській активності. У зв’язку 3 цим постає проблема об'єктивного та верифікованого оцінювання наукової діяльності студентів, яке було б розроблено з врахуванням інформаційних освітніх технологій. Доцільним вважаємо використання інформаційної технології електронного портфоліо - це дозволяє оперативно та ефективно оцінити наукову активність кожного претендента на академічну стипендію.

Аналіз актуальних досліджень. Осмислення зарубіжного та вітчизняного досвіду використання електронного портфоліо зроблено у наукових працях Т. Івлевої [2], В. Квас [3], Т. Панченко [4], О. Смолянинової [5] та інших вчених. Питання ефективного моніторингу та оцінювання знань розглядається у грунтовній праці Л. Ярощук [6]. Перехід ВНЗ до автоматизованої системи оцінювання наукової діяльності студентів є важливим елементом створення інформаційного суспільства в Україні. Як стверджує Л. Хоменко, "підготовка суспільної свідомості до рівня потреб сучасної інформаційної культури поєднана 3 проблемою масового пробудження у кожного громадянина інтересу до алгоритмізації та комп'ютеризації процесів своєї персональної діяльності, 3 проблемою зрушення соціальної психології від традиційних стереотипів волевиявлення (яке межує з елементами свавілля) - до ідей прийняття рішень на базі комп'ютерної обробки даних, з проблемою формування могутнього соціального (в тому числі - і матеріального) стимулу, досвіду та знань, обов'язкових для успіху політики інформатизації" [7: 166].

Формулювання мети і завдань статті. Мета статті полягає у дослідженні потенціалу інформаційної освітньої технології електронного портфоліо для оперативного та об'єктивного рейтингування наукових досягнень студентів ВНЗ. Мета статті передбачає наступні завдання: характеристика електронного портфоліо як інформаційної освітньої технології; визначення ефектів, які досягаються завдяки створенню єдиної бази електронних портфоліо наукових робіт студентів.

Виклад основного матеріалу. Технологія електронного портфоліо належить до технологій оцінювання, іiі сутність полягає у накопиченні, зберіганні та презентації індивідуально значущих результатів.

Електронне портфоліо, як інформаційна технологія, виникла у США, у світовій практиці електронне портфоліо $\epsilon$ частиною стратегії електронного навчання, яка визнана найбільш перспективною технологією навчання в даний час. В Україні ця освітня технологія використовується спорадично, про ще свідчить, зокрема, відсутність відповідної статті у спеціалізованих наукових словниках, зокрема у словнику-глосарії колективу авторів на чолі з М. Кадемія [8], у якому подано лише дефініцію електронної колекції. Поняття електронної колекції є близьким до електронного портфоліо, вона визначається авторами як "множина електронних документів, що мають однотипні формальні ознаки і містять фактографічну інформацію" [8].

Існує ряд визначень, що уточнюють і пояснюють термін "навчальне портфоліо":

- антологія робіт, аналіз і самооцінка цих робіт; 
- $\quad$ виставка навчальних досягнень по даній дисципліні (або кількох споріднених дисциплінах) за даний період навчання (семестр, курс);

- $\quad$ колекція робіт, що всебічно демонструє не тільки його навчальні результати, але й зусилля, прикладені до їхього досягнення, а також очевидний прогрес у знаннях і вміннях у порівнянні 3 попередніми результатами;

- систематичний і спеціально організований збір доказів, використовуваних для моніторингу знань, навичок;

- спосіб фіксування, накопичення й оцінки індивідуальних досягнень;

- форма цілеспрямованої, систематичної й безперервної оцінки й самооцінки навчальних результатів [3: 54].

У даному дослідженні під електронним портфоліо розуміємо сукупність наукових робіт студента, зібраних із застосуванням електронних засобів і носіїв. Крім власне наукових робіт електронне портфоліо може містити інформацію про участь у наукових конференціях, олімпіадах, конкурсах наукових робіт або інших творчих конкурсах, проектну діяльність, отримані гранти, персональні стипендії тощо, тобто усе, що пов'язане з науковою активністю студента.

Електронне порфоліо може бути представлене або на цифровому носії інформації, так зване еportfolio, або у вигляді web-сайту, тобто online-portfolio. Останній тип портфоліо вважаємо більш ефективним, оскільки він повніше відповідає вимогам рейтингування наукових досягнень студентів ВНЗ, критеріям об'єктивності оцінювання, цілям і задачам web-базованого навчання.

Онлайн-портфоліо студента, що претендує на академічну стипендію, - це серія наукових робіт одного автора, об’єднаних у один електронний документ і викладений на сайті університету.

Основною метою створення електронного портфоліо $є$ забезпечення верифікованого моніторингу наукових досягнень студента, аналіз і подання значущих результатів процесів його компетентнісного і особистісного зростання. Електронне портфоліо дозволяє враховувати результати, досягнуті студентом у науковій діяльності.

На даний момент студенти Кременчуцького національного університету імені Михайла Остроградського для одержання академічної стипендії заповнюють від руки бланк картки підтримки бакалавра і до нього докладають ксерокопії наукових робіт. Такий застарілий процес підтвердження наукової активності породжує цілу низку проблем з обрахуванням індивідуальних рейтингів, адже паперові документи часто губляться, виникає плутанина, а іноді й підробка документів; працівники деканатів витрачають тривалий час на перевірку достовірності поданих документів і систематизацію даних.

Вимоги об’єктивного і верифікованого обліку наукової діяльності студентів передбачають:

- створення у ВНЗ єдиної автоматизованої системи індексування наукових робіт студентів;

- $\quad$ розробку програмного забезпечення, яке б дозволяло оперативно складати рейтинг студентів.

Функціонал електронного портфоліо наукових досягнень студента повинен містить такі операції, як завантаження власних наукових робіт, перевірка їх на унікальність тексту, індекс цитування тощо. Електронне портфоліо забезпечує накопичення інформації, пов'язаної з науковою діяльністю, дозволяє у он-лайн-режимі відстежувати професійне зростання, підвищення кваліфікації студента.

Розробка єдиної індексного-рейтингової системи оцінювання наукових досягнень студентів передбачає створення механізмів співвіднесення кількісних і рангових шкал, що застосовуються в бально-рейтинговій системи, і дескриптивних шкал оцінювання електронного портфоліо.

У зв'язку з цим в процесі всього навчання студентам необхідно вміти безперервно виробляти самооцінку і аналіз своєї освітньої та наукової діяльності, вибудовувати індивідуальну траєкторію навчання і бачити перспективи навчально-професійного розвитку. Майбутній фахівець повинен вміти проводити моніторинг свого професійного становлення, аналізувати і представляти результати компетентнісного і особистісного зростання, а також презентувати свої досягнення і продукти своєї інтелектуальної діяльності за допомогою сучасних інформаційних технологій. Варто зазначити, що володіння сучасними інформаційними технологіями входить до системи загальних компетентностей усіх освітньо-професійних і освітньо-наукових програм, спеціальностей і галузей знань. На сьогоднішній день це базова компетентність, без якої кваліфікація будь-якого фахівця не є достатньою.

Мета процесу розробки студентом електронного портфоліо полягає також в тому, щоб дати можливість студенту осмислювати власні досягнення. Оформлення портфоліо вимагає від студентів безперервності й цілеспрямованості участі у науковій діяльності, що мотивує їх на особистісні, наукові й академічні досягнення у процесі навчання. Електронне портфоліо допомагає викладачам та власнику портфоліо контролювати та оцінювати процес навчання протягом всього періоду. Портфоліо, як інструмент оцінювання, можуть бути частково інтегровані в навчальні плани.

Відзначимо, що в траєкторії навчання студента повинні бути відзначені точки внесення змін і доповнень в електронне портфоліо з його оцінкою усіма учасниками освітнього процесу спільно. Отже, і викладачеві, і студенту стає очевидним шлях наукового руху і розвитку. 
Створення бази онлайн-портфоліо наукових досягнень студентів забезпечує передумови для здорової конкуренції, активізує наукову діяльність студентів, запобігає корупції у закладах вищої освіти. Унаочнення і оприлюднення студентських наукових досягнень, чітка й прозора система рейтингування знижує можливість зловживань, а також дозволяє уникати конфліктів у студентському середовищі на грунті одержання чи неодержання певних оцінок, i, як наслідок, академічних стипендій. Необхідною умовою цього є розробка єдиної автоматизованої індексно-рейтингової системи оцінювання.

Будучи засобом автентичного оцінювання, що застосовуються в практико-орієнтованому i особистісно-орієнтованому освіті, технологія портфоліо доповнює бально-рейтингову систему, оскільки дає можливість акумулювати і враховувати кількісні та якісні оцінки і комплексно оцінювати як можливості самореалізації студента в освітньому середовищі вищого навчального закладу, так i індивідуальні предметні, метапредметні та особистісні результати [4].

Варто додати, що створення єдиної бази студентських наукових робіт полегшує процес їх перевірки програмою Антиплагіат 3 метою визначення ступеня оригінальності тексту. Це сприяє втіленню концепції академічної доброчесності, яка $є$ невід’ємною складовою сучасної реформи української вищої школи. На даний момент культура наукової діяльності в українській вищій освіті, передусім у сегменті студентської науки, викликає певні зауваження: часто студенти формально ставляться до наукової роботи, порушують норми наукової етики, створюючи компілятивні праці, запозичуючи чужі думки, ідеї, тексти. Трапляються випадки, коли співпадають навіть назви наукових чи кваліфікаційних робіт. Це спотворює становлення особистості молодих фахівців, негативно впливає на подальшу професійну діяльність, уповільнює як власний розвиток української науки і техніки, так і процес входження іiі у світовий науковий простір.

На нашу думку, перспектива того, що наукова робота студента потрапить у відкритий доступ і буде зберігатися в електронному вигляді необмежений час, є запорукою того, щоб студентські наукові розвідки були стовідсотково унікальними. Таким чином, електронне портфоліо наукових робіт студентів безпосередньо впливатиме на культуру наукового цитування, підвищення самостійності наукової праці. Опанування вмінням коректного i адекватного наукового цитування, в свою чергу, $є$ фактором формування наукових колективів і наукових шкіл. Слід пам'ятати, що сьогодні в Україні, як і в розвинених країнах, індекс цитування є одним з основних критеріїв оцінки результативності вченого.

Для ефективного функціонування технології необхідно, щоб база студентських наукових електронних портфоліо була поєднана системою взаємопосилань із репозитарієм бакалаврських та магістерських кваліфікаційних робіт. Це створить передумови наступності студентської наукової діяльності, можливості посилатися на роботи колег, як 3 попередніх курсів, так і 3 інших спеціальностей i факультетів. Зараз пошук наукових робіт студентів ускладнюється тим, що кваліфікаційні роботи випускників викладаються у відкритий доступ далеко не всіма вищими навчальними закладами, це стосується і збірок наукових праць, і матеріалів студентських наукових конференцій. На жаль, у наш час, коли майже вся інформація присутня в електронному варіанті, саме студентські роботи залишаються переважно у паперовому вигляді.

Крім того, єдина база електронних портфоліо студентських наукових робіт дозволяє значно спростити процес експертної перевірки та оцінки якості освітньої діяльності вищого навчального закладу в аспекті моніторингу участі студентів у науковій діяльності. Ця складова освітнього процесу (студентська наука) на даний момент є останньою, якої немає у відкритому доступі в систематизованому вигляді. Якщо науковий доробок професорсько-викладацького складу вищого навчального закладу представлений на сайтах кафедр і факультетів, то єдина база наукових робіт студентів там поки що не подається. До речі, це порушує принцип послідовності наукової діяльності, оскільки унеможливлює простежити наукову траєкторію науковця із самого початку.

Варто також зазначити, що пропонована єдина база електронних портфоліо студентських наукових робіт може стати корисним інструментом для організації виробничої практики студентів, стажування, виконання проектів і подальшого працевлаштування випускників вищих закладів освіти. Потенційні керівники практики від підприємств та роботодавці можуть самостійно переглянути наукові досягнення майбутніх працівників, виявити найбільш перспективних або обрати тих фахівців, чия тематика і якість досліджень найкраще відповідають специфіці певного підприємства чи організації. Електронне портфоліо наукових досягнень студента дозволяє виявити переваги конкретного претендента на посаду порівняно з іншими значно ефективніше, ніж стандартні характеристика, автобіографія чи резюме. Таким чином, інформаційна технологія електронного портфоліо стає не лише інструментом планування і побудови професійної кар'єри, а й технологією особистісного і професійного розвитку. Електронне портфоліо підвищує відповідальність студентів за навчальний процес.

У Кременчуцькому національному університеті імені Михайла Остроградського найближчим часом планується розробка і затвердження Положення про електронне портфоліо наукових досягнень студентів, у якому окреслюється галузь застосування технології, цілі і завдання, структура і зміст, оформлення, суб’єкти та порядок функціонування технології. Також заплановано розробку методичних 
рекомендацій для студентів, які б містили поради зі створення і роботи з електронним портфоліо, а також організацію циклу вебінарів 3 цього питання для студентів і викладачів. Такий комплекс мір здатний забезпечити ефективне впровадження технології електронного портфоліо в освітній процес.

Висновки та перспективи подальших досліджень. Розробка єдиної автоматизованої системи моніторингу й оцінювання наукової діяльності студентів, яка передбачає створення єдиної бази електронних портфоліо студентів і презентацію іiі на сайті ВНЗ, створює передумови поліпшення механізму залучення студентів до наукової діяльності, а також є дієвим способом оптимізації процесу матеріального заохочення студентів. Сучасні зміни освітньої галузі, які підвищують самостійність вишів у змісті освітньо-професійних програм та оцінці якості навчання студентів, також є аргументом на користь використання технології електронного портфоліо. Інформаційна технологія електронного портфоліо сприяє прозорості та відкритості системи вищої освіти. Також технологія є ефективним інструментом стимулювання професійного зростання студентів та їх успішного працевлаштування. Перспективним напрямком подальших досліджень $\epsilon$ розробка алгоритму створення індивідуального електронного портфоліо та єдиної автоматизованої бази даних, а також організація педагогічного експерименту з метою визначення ефективності даної інформаційної освітньої технології.

\section{СПИСОК ВИКОРИСТАНИХ ДЖЕРЕЛ ТА ЛІТЕРАТУРИ}

1. Постанова Кабінету міністрів України "Деякі питання стипендіального забезпечення" від 28 грудня 2016 р., № 1050 [Електронний ресурс]. - Режим доступу : http://www.kmu.gov.ua/control/uk/cardnpd?docid=249638784.

2. Ивлева Т.Н. Технология электронного портфолио в подготовке менеджеров социальнокультурной деятельности / Т. Н. Ивлева // Вестник Кемеровского государственного университета культуры и искусств. - 2012. - № 2 (19-2). - С. 156-163.

3. Квас В. М. Використання технологій портфоліо у системі вищої освіти / В. М. Квас // Вісник Черкаського університету : Серія Педагогічні науки. -2010. - Вип. 186. - С. 53-60.

4. Панченко Т. В. Условия внедрения технологии электронного портфолио в контексте требований ФГОС ВО [Електронний ресурс] / Т. В. Панченко // Дискуссия. - 2016. - № 9 (72). - Режим доступу до журн. : http://www.journal-discussion.ru/publication.php?id=1692.

5. Смолянинова О. Г. Технология электронного портфолио: российский и зарубежный опит : [монографія] / О. Г. Смолянинова. - Красноярск : Сибирский федеральный университет, 2012. - 332 с.

6. Ярощук Л. Основи педагогічних вимірювань та моніторингу якості освіти: [навчальний посібник] /Л. Ярощук. - К. : Слово, 2010. - 304 с.

7. Хоменко Л.Г. Електронна інформаційна цивілізація : досвід розбудови в Україні : [монографія] / Л. Г. Хоменко. - К. : Міжнар. агенц. "BeeZone", 2004. - 200 с.

8. Кадемія М. Ю. Інформаційно-комунікаційні технології навчання : словник-глосарій / М. Ю. Кадемія, М. М. Козяр, Т. Є. Рак. - Львів : СПОЛОМ, 2011. - 327 с.

\section{REFERENCES (TRANSLATED \& TRANSLITERATED)}

1. Postanova Kabinetu ministriv Ukraini "Deiaki pitannia stipendial'nogo zabezpechennia" vid 28 grudnia 2016 r., № 1050 [Resolution of the Cabinet of Ministers of Ukraine "Some Issues of Scholarship Support" dated December 28, 2016, No. 1050] [Elektronnyi resurs]. - Rezhym dostupu : http://www.kmu.gov.ua/control/uk/cardnpd?docid=249638784.

2. Ivleva T. N. Tekhnologiia elektronnogo portfolio v podgotovke menedzherov sotsial'no-kul'turnoi deiatel'nosti [Technology of Electronic Portfolio in the Training of Managers of Social and Cultural Activities] / T. N. Ivleva // Vestnik Kemerovskogo gosudarstvennogo universiteta kul'tury i iskusstv [Bulletin of Kemerovo State University of Culture and Arts]. - 2012. - № 2 (19-2). - S. 156-163.

3. Kvas V. M. Vikoristannia tekhnologii portfolio u sistemi vishchoi osvity [Using Technologies of Portfolio in the Higher Education System] / V. M. Kvas // Visnik Cherkas'kogo universitetu : Seriia Pedagogichni nauki [Cherkassy University Bulletin. Series of Pedagogical Sciences]. - 2010. - Vyp. 186. - S. 53-60.

4. Panchenko T. V. Usloviia vnedreniia tekhnologii elektronnogo portfolio $\mathrm{v}$ kontekste trebovanii FGOS VO [Conditions for the Introduction Electronic Portfolio Technology in the Context of the FSS HE Requirements] [Elektronnyi resurs] / T. V. Panchenko // Diskussiya [Discussion]. - 2016. - № 9 (72). - Rezhym dostupu : http://www.journal-discussion.ru/publication.php?id=1692.

5. Smolianinova O. G. Tekhnologiia elektronnogo portfolio: rossiyskiy i zarubezhnyy opyt : [monografiia] [Technology of Electronic Portfolio: Russian and Foreign Experience: monograph] / O. G. Smolianinova. Krasnoiarsk : Sibirskiy Federal'nyy Universitet, 2012. - 332 s.

6. Yaroshchuk L. Osnovy pedagogichnikh vimiryuvan' ta monitoringu yakosti osviti [Fundamentals of Pedagogical Measurement and Monitoring of Quality of Education] : [navchal'nyi posibnyk] / L. Yaroshchuk. - K. : Slovo, 2010. $-304 \mathrm{~s}$.

7. Khomenko L. G. Elektronna informatsiina tsivilizatsiia : dosvid rozbudovi v Ukraini : [monografiia] [Electronic Information Civilization : Experience of Development in Ukraine] / L. G. Khomenko. - K. : Mizhnar. agents. "BeeZone", 2004. - 200 s.

8. Kademiia M. Yu. Informatsiino-komunikatsiini tekhnologii navchannia : slovnik-glosarii [Information and Communication Technologies of Teaching : dictionary-glossary] / M. Yu. Kademiya, M. M. Kozyar, T. E. Rak. L'viv : SPOLOM, 2011. $-327 \mathrm{~s}$. 


\section{Грицюк Е. С. Использование информационной технологии электронного портфолио в образовательном процессе вуза.}

В статье рассмотрена роль информационной технологии электронного портфолио в активизации научной деятельности студентов вуза и в процессе мониторинга и оценки её результатов с иелью оптимизации составления рейтинга успешности. Создание в информационной среде вуза базы электронных портфолио научных достижений студентов способствует построению единой автоматизированной индексно-рейтинговой системы оценивания.

Ключевые слова: электронное портфолио, информаџионные технологии в образовании, научная деятельность, составление рейтинга.

\section{Grytsiuk O. S. Use of Electronic Portfolio Information Technology in the Educational Process of the University.}

The research considers the role of electronic portfolio as information technology in the activation of students' scientific activity and in the process of monitoring and evaluation of its results with the purpose of optimizing the success ranking. The scientific methods of analysis, synthesis and description have been used in order to define the term "electronic portfolio". The generalization and systematization of scientific statements have been used to determine the characteristics and effective forms of work with e-portfolio. The main purpose of creating an electronic portfolio is to provide verified monitoring of student's scientific achievements, analysis and presentation of meaningful results of its competence and personal growth. The electronic portfolio allows taking into account the results achieved by the student in scientific activity. Creating an online portfolio database of

students' academic achievements provides a prerequisite for healthy competition and activates students' scientific activity, prevents corruption. Creation the base of electronic portfolio of students' scientific achievements in the university information environment contributes to the construction a unified automated index-rating system of evaluation. The united base of student scientific work facilitates the process of their verification by the Anti-Plagiarism program, that is, it supports the academic integrity concept. Electronic portfolio information technology contributes to the transparency and openness of the higher education system.

Key words: electronic portfolio, information technologies in education, scientific activity, rating. 